\title{
Do Estado de Direito ao Estado de Justiça ${ }^{1}$
}

\author{
From the Rule of Law to the Rule of Justice
}

\author{
João dos Passos Martins Neto \\ Universidade Federal de Santa Catarina, Florianópolis - SC, Brasil
}

Bárbara Lebarbenchon Moura Thomaselli

Universidade Federal de Santa Catarina, Florianópolis - SC, Brasil

Resumo: Estado de Direito é um termo que normalmente designa a autoridade e a influência da lei sobre a sociedade. À luz da história, duas principais modalidades de Estado de Direito podem ser identificadas: a formalista e a substantiva. No Estado de Direito do tipo substantivo, que reflete a experiência das modernas democracias ocidentais, a marca decisiva é a adesão à doutrina dos direitos naturais e ao sistema de direitos humanos que congregam as ideias de justiça compartilhadas pela maior parte dos povos e nações do mundo no estágio atual da civilização humana.

Palavras-chave: Estado de Direito. Direitos Fundamentais. Estado Constitucional. Estado de Justiça.

\begin{abstract}
The Rule of Law generally refers to the authority and influence of law in society, especially as a constraint upon behavior. In light of history, at least two principal types of the Rule of Law can be identified: a formalist one, and a substantive one. Under substantive Rule of Law, which reflects the experience of Western democracies nowadays, the decisive mark is the adherence to the natural rights doctrine and to the human rights international system which embrace the ideas of justice shared by the majority of people and nations of the world at the present stage of human civilization.
\end{abstract}

Keywords: The Rule of Law. Fundamental Rights. Constitutional State. The Rule of Justice.

1 Recebido em: 09/08/2013

Revisado em: 21/10/2013

Aprovado em: 26/10/2013 


\section{Introdução}

No discurso político e acadêmico, Estado de Direito é uma categoria frequentemente utilizada, mas nem sempre com igual significado. De acordo com Ferrajoli (2003, p. 13, tradução nossa), em sentido amplo, Estado de Direito designa qualquer "[...] ordenamento em que os poderes públicos são conferidos pela lei e exercitados nas formas e com os procedimentos legalmente estabelecidos" ". Por outro lado, em sentido estrito - e também forte -, Estado de Direito designa aqueles “[...] ordenamentos nos quais todos os poderes públicos estão sujeitos à lei, não apenas com relação às formas, mas também com relação aos conteúdos"3 (FERRAJOLI, 2003, p. 13, tradução nossa). Nessa acepção, apenas são considerados Estados de Direito os ordenamentos em que todos os poderes, especialmente o legislativo, estão vinculados a preceitos substantivos estabelecidos por meio de normas constitucionais que prestigiam a divisão de poderes e os direitos fundamentais (ZAGREBELSKY, 2002, p. 21-34). Ferrajoli (2003) observa que ambos os conceitos descrevem realidades políticas diferentes. O primeiro refere-se ao modelo positivista do Estado de Direito de caráter formalista, que surge com o nascimento do Estado Moderno a partir da centralização da produção jurídica. O segundo corresponde ao modelo neoconstitucionalista do Estado Constitucional de Direito, ou Estado Constitucional, produto da difusão na Europa, após a Segunda Guerra Mundial, das Constituições rígidas e do controle de constitucionalidade das leis infraconstitucionais. Segundo Ferrajoli (2003), os dois modelos refletem experiências históricas, ocorridas no continente europeu, decorrentes da alteração de paradigmas da estrutura do direito, da ciência jurídica e da jurisdição. Neste artigo, pretende-se explicar e explicitar as notas distintivas dessas duas versões de Estado de Direito, a fraca e a forte, a formalista e a substantiva, as quais serão referidas ao longo da exposição, em atenção a objetivos de maior claridade,

\footnotetext{
2 Ordenamiento en el que los poderes públicos son conferidos por la ley y ejercitados em las formas y con los procedimientos legalmente establecidos.

3 Estado de Derecho designa, en cambio, sólo aquellos ordenamientos en los que los poderes públicos están, además, sujetos a la ley (y, portanto), limitados o vinculados por ella), no sólo en lo relativo a las formas, sino también em los contenidos.
} 
simplesmente pelos termos Estado Legal de Direito e Estado Constitucional de Direito.

\section{O Estado Legal de Direito}

O Estado Legal de Direito está em íntima conexão com o advento do Estado Moderno, que se forma na Europa entre o século XIII e o fim do século XVIIII. O Estado Moderno se apresenta basicamente como uma unidade de comando das relações de vida num espaço territorial relativamente amplo, realizada por meio da concentração do poder de ditar normas de comportamento e de sancionar a conduta ilícita. Consolida-se quando a monarquia finalmente se impõe ao modo de configuração político-jurídica típica do medievo, marcada pela existência concomitante de uma pluralidade de estruturas de poder, com destaque para a Igreja Romana - cuja liderança clerical afirmava a supremacia dos cânones divinos por ela revelados - e para o senhor feudal, que no círculo de sua propriedade exercia um domínio autônomo. A unidade jurídico-política viabiliza-se através do monopólio da força, que se traduz pelo exercício exclusivo do poder de legislar (monopólio da legislação) e de julgar (monopólio da jurisdição) no espaço territorial das novas comunidades nacionais. Implicando a redução do conteúdo do direito às leis e decisões emanadas do poder estatal, o monopólio da força retira a quaisquer outros pretensos poderes, sobretudo o eclesiástico, o direito de organizar a vida em sociedade e, assim, assegura a edificação de um único ordenamento vinculante.

Com efeito, diz Ferrajoli (2003, p. 15, tradução nossa), no direito anterior, ou pré-moderno, não havia tradição ou formação legislativa, mas apenas jurisprudencial e doutrinária, ou seja,

[...] inexistia um sistema unitário e formalizado de fontes positivas, mas, ao contrário, uma pluralidade de fontes e ordenamentos procedentes de instituições diferentes e concorrentes - do Império, da 
Igreja, dos príncipes, dos municípios, das corporações - nenhuma delas com o monopólio da produção jurídica ${ }^{4}$.

O reconhecimento de uma norma como jurídica não dependia da sua fonte de produção, mas de sua racionalidade intrínseca ou da justiça dos seus conteúdos.

Com o ocaso do mundo medieval e o ingresso na era moderna, a ordem político-jurídica muda radicalmente, sobretudo pela afirmação do princípio da legalidade como critério de identificação do direito válido e existente, independentemente de sua valoração como justo. Uma norma jurídica não é mais válida por ser justa, mas, exclusivamente, por ter sido "posta" por uma autoridade dotada de competência legislativa. Verifica-se aí a inversão do princípio jusnaturalista, até então vigente, veritas, non auctoritas facit iudicium. Agora, diz-se que auctoritas, non veritas facit legem, princípio do positivismo jurídico do Estado Legal de Direito. Hespanha (2005, p. 341) assinala, a propósito, que a nova ordem política chega à sua fase de institucionalização depois do período "programático e experimental" correspondente à metodologia jusnaturalista da sociedade medieval. Ele registra que, no plano jurídico, "[...] esta fase caracteriza-se pelo movimento legalista e, sobretudo, pela tendência codificadora". (HESPANHA, 2005, p. 341)

O Estado qualifica-se então como uma organização na qual o direito é assimilado à lei, que passa a ser considerada, de acordo com Goyard-Fabre (2002), em seu componente formal e não em seu componente material. Nas lições de Ferrajoli (1999), o Estado adota o princípio da superioridade da lei, equivalente ao princípio jacobino da onipotência do legislador, e, portanto, do parlamento como órgão de soberania popular, que não encontra nenhum limite, senão formal, para a produção normativa.

\footnotetext{
4 En el Derecho premoderno, de formación no legislativa, sino jurisprudencial y doctrinal, no existía un sistema unitario e formalizado de fuentes positivas, sino una pluralidade de fuentes y ordenamientos procedentes de instituciones diferentes y concurrentes - el Imperio, la Iglesia, los príncipes, los municipios, las corporaciones - ninguma de las cuales tenía el monopolio de la producción jurídica.
} 
Canotilho (1999) ressalta, na mesma linha de pensamento, que o Estado de Legal de Direito incorpora a ideia do primado da lei com base na doutrina da soberania nacional representada pelo poder legislativo. $\mathrm{O}$ princípio da primazia da lei conduzia à submissão do poder político ao direito, sob um duplo ponto de vista: os cidadãos têm a garantia de que a lei só pode ser editada pelo órgão legislativo, isto é, o órgão representativo da vontade geral; e essa lei constitui a fonte de direito hierarquicamente superior e, por isso, todas as medidas adotadas pelo poder executivo deviam estar em conformidade com ela. Entretanto, sob esse modelo, existe tão somente uma vinculação formal à lei, porquanto ainda que o direito estabeleça a forma de produção jurídica, não reconhece qualquer limitação de conteúdo, de modo que inexistem âmbitos de exclusão das possibilidades de regulação. O direito apresenta-se assim, de acordo com Cademartori (1999, p. 25), “[...] esvaziado de qualquer referente substancial ou material e passa a ser uma forma vazia a ser preenchida por qualquer conteúdo".

De acordo com Ferrajoli (2003), o advento do Estado Legal de Direito foi acompanhado, ainda, de uma alteração de paradigma com relação à ciência jurídica. A partir da afirmação do princípio de legalidade como norma de reconhecimento do direito válido e existente, a ciência jurídica deixa de ser uma ciência imediatamente normativa para converter-se em uma disciplina tendencialmente cognitiva, ou seja, explicativa de um objeto, o direito positivo, autônomo e separado dela. Ferrajoli (2003, p. 16-17, tradução nossa) sublinha que, embora uma comparação entre o Código Civil Napoleônico e as Instituições de Gaio não apontem diferenças substanciais, "[...] o que deve ser ressaltado como a grande alteração é o título de legitimação, que deixa de ser a autoridade dos doutores, para ser a autoridade da fonte de produção" ". Enfim, somente a lei e o princípio da legalidade são as fontes de legitimação e de produção de normas jurídicas. Disso resulta, ainda, a quebra do paradigma da jurisdição, porquanto o direito jurisprudencial é superado, submetendo-se o direito à lei e ao princípio da legalidade como fontes únicas de legitimação.

5 Lo que cambia es el título de legitimación, que ya no es la autoridade de los doctores, sino la autoridade de la fuente de producción. 
Zagrebelsky (2002) aprofunda a análise observando que o Estado Legal de Direito se afirma através do princípio da legalidade, expressando a ideia da lei como ato normativo supremo e irresistível ao qual, em linha de princípio, não é oponível nenhum direito mais forte, qualquer que seja sua forma e seu fundamento, vale dizer, nem o poder de exceção do rei e de sua administração, em nome de uma superior "razão do Estado", nem a aplicação, por parte dos juízes, ou a resistência dos particulares, em nome de um direito mais alto, o direito natural, ou de direitos especiais.

De acordo com o magistério de Barroso (2003), o positivismo jurídico, característico do Estado de Direito em sua fase inicial, correspondeu à importação do positivismo filosófico para o mundo do direito, na pretensão de criar-se uma ciência jurídica com características análogas as das ciências exatas e naturais. Nesse contexto, o direito é norma, ato emanado do Estado com caráter imperativo e força coativa, de modo que a ciência do direito deveria fundar-se em juízos de fato, que visam ao conhecimento da realidade, e não em juízos de valor, que representam uma tomada de posição diante da realidade. A discussão sobre questões como legitimidade e justiça não deveria, portanto, ser tratava no âmbito do direito, devendo separar-se direito e moral.

$\mathrm{Na}$ história da filosofia política, o Estado Legal de Direito encontra correspondência no pensamento de Hobbes, para quem a soberania é indivisível e ilimitada (ou absoluta). Hobbes realmente não é um adepto da doutrina da separação de poderes, tal como Locke e Montesquieu. Por outro lado, segundo ele, o soberano, quando no exercício da função legislativa, não está obrigado a observar, por inexistentes, quaisquer preceitos normativos de validade superior, quer jurídicos, quer morais, quer divinos, podendo dispor livremente do conteúdo das leis e criando direito válido sob o só fundamento da sua autoridade. Em Hobbes, contudo, é enorme o prestígio da lei como técnica regular de controle social. O súdito só tem obrigação na medida das imposições legais, e desde que delas tenha tido prévia ciência; desfruta de liberdade plena para atuar conforme queira sempre que não houver regulação em contrário; e não deve ser condenado senão por um ato ilegal, nem punido senão após devidamente julgado como transgressor. Por isso, seu absolutismo não se define como um modelo totalmente carente de referências jurídicas. A pedra de toque 
da distinção diz respeito à falta de dois específicos mecanismos de limites ao exercício do poder que só serão afirmados num segundo momento da evolução do Estado Moderno, a divisão de poderes e os direitos fundamentais.

De fato, sobretudo ao fundar-se sob o princípio da soberania ilimitada, ou de que o soberano é legibus solutus, Hobbes distancia-se de uma concepção que reconheça quaisquer direitos como oponíveis à atividade legislativa. Seu modelo de Estado é ainda o de um Estado de Direito, porém de caráter formalista, à medida que, recusando-se a admitir a sujeição do poder legislativo a limites jurídico-materiais, ele nega os dois pressupostos elementares do modelo de soberania limitada que surge a partir da filosofia de Locke: a existência de regras substantivas de escalão superior (os chamados direitos naturais) e a vinculação estrita do legislador ao respectivo respeito. No Estado de Hobbes, o detentor do poder soberano atua por meio de leis, mas as produz livre de condicionamentos, porque não são reconhecidos âmbitos de exclusão de sua competência legislativa (nem leis positivas, nem divinas, nem morais).

O formalismo jurídico é claríssimo em Hobbes. A soberania ilimitada é, em sua filosofia, uma consequência lógica do modo como ele concebe o pacto de instituição do Estado. Para ele, trata-se de um acordo pelo qual os indivíduos isolados apenas transferem o poder de organizar a sociedade a um terceiro, mas sem fazer reserva de supostos direitos naturais. $\mathrm{O}$ pacto restringe-se a estabelecer a autoridade competente para legislar, mas sem antepor qualquer conteúdo normativo como indisponível ou intocável. Não se reconhece a eficácia, em favor dos indivíduos, de direitos anteriores à instituição do poder político, entendidos como limites de conteúdo postos ao legislador constituído. Hobbes (1998, p. 110) não admite sequer - como às vezes se pensa - o direito à vida como oponível, em sentido jurídico, ao soberano; ele aceita o direito do súdito a não se conformar com a pena de morte, podendo legitimamente resistir, mas ainda assim podendo legitimamente ser morto em cumprimento da condenação.

O absolutismo de Hobbes ganha maior claridade quando confrontado com a filosofia política de Locke, o grande teórico da soberania limita- 
da. Em Locke (1973, p. 269), a vida, a liberdade e a propriedade são descritas como barreiras à extensão do supremo poder legislativo. São bens outorgados a cada homem pela lei da natureza, contra a qual “[...] não há sanção humana que se mostre válida ou aceitável”. O pacto de fundação do Estado não implica jamais a sua alienação; antes impõe ao soberano um respeito incondicional. Assim, apoiando-se numa concepção de contrato que compreende nítida reserva de conteúdos vinculantes (os direitos naturais), Locke acolhe um princípio diverso daquele do absolutismo: para ele, a soberania é limitada. Com isso, Locke projeta um Estado de Direito de caráter material ou substantivo, à medida que submete o poder a preceitos anteriores e superiores que jamais podem ser negados.

É importante notar que, em Hobbes, o absolutismo, assim entendido, aparece ligado à sua clara opção pelo positivismo jurídico, ou seja, pela concepção de que, uma vez abandonado o estado de natureza, o único direito reconhecível como válido é o direito posto pela autoridade estatal. Hobbes (1983, p. 162) é suficientemente explícito ao escrever que "o Estado é o único legislador". Vale destacar ainda que, por óbvio, Hobbes produziu sua obra em uma época ainda distante do advento do constitucionalismo, ou seja, do sistema de direito positivo estruturado em forma de pirâmide hierárquica, no interior do qual são estabelecidas normas de validade superior (as constitucionais) em relação às restantes normas do ordenamento jurídico (as infraconstitucionais).

Em suma, o Estado Legal de Direito pode ser conceituado como o modo de organização político-jurídica no qual, embora constituindo a lei emanada do poder público o instrumento de regência da vida em sociedade, o poder legislativo encontra-se limitado apenas por regras que definem as autoridades habilitadas a legislar e a forma pela qual devem proceder. Nesse sentido, embora limites jurídicos existam, eles são de natureza formal, isto é, relativos à competência do legislador e ao modo de legislar. O legislador, com autoridade para criar o direito e desde que observe o rito prescrito, é livre quanto ao conteúdo das leis, podendo imprimir qualquer direção à matéria de sua deliberação. Seus comandos, quaisquer que sejam, são obrigatórios, uma vez que validade da lei depende só do respeito à competência e ao procedimento. $\mathrm{O}$ recurso à lei como medida das condutas lícitas e ilícitas tende a gerar previsibilidade, mas 
ainda assim a fragilidade do modelo é evidente. Mesmo que juízos morais, tradições culturais e circunstâncias políticas possam, na prática, conter um legislador benigno, não há, no plano jurídico, nenhuma segurança contra um legislador maligno, ou contra a expedição de uma norma que afronte padrões mínimos de justiça reconhecidos no curso da história da civilização. No Estado Legal de Direito, essa garantia não existe porque falta nele uma lei que, fixando salvaguardas contra a iniquidade, seja qualificada como fundamental, vinculante, superior às demais e, em parte, irrevogável, segundo precisamente a lógica do constitucionalismo.

\section{O Estado Constitucional de Direito}

O Estado Constitucional de Direito surge da crise da legalidade. Segundo Barroso (2003, p. 25), a "ambição positivista de certeza jurídica" custou caro à humanidade. A ideia de que o debate acerca da justiça se encerrava quando da positivação da norma tinha um caráter legitimador de qualquer ordem estabelecida, de modo que o "[...] fetiche da lei e o legalismo acrítico, subprodutos do positivismo jurídico, serviram de disfarce para autoritarismos de matizes variados". (BARROSO, 2003, p. 26)

De fato, a decadência do positivismo é emblematicamente associada à derrota do fascismo na Itália e do nazismo na Alemanha, porquanto esses movimentos políticos e militares ascenderam ao poder dentro do quadro de legalidade vigente e promoveram a barbárie em nome da lei. Como destaca Barroso (2003), os principais acusados de Nuremberg invocaram o cumprimento da lei e a obediência a normas emanadas da autoridade competente, o que determinou a rejeição da ideia até então cristalizada de um ordenamento jurídico indiferente a valores éticos e da lei como uma estrutura meramente formal, uma embalagem para qualquer produto.

Nas palavras de Cademartori (1999, p. 29), a norma geral e abstrata deixa de ser considerada "[...] instrumento adequado para assegurar a paz social e, particularmente, a indisponibilidade daqueles valores e princípios com respeito aos quais existe um amplo consenso social". A lei não é mais a expressão pacífica de uma sociedade política internamente coeren- 
te, como a medieval, mas passa a ser percebida como um ato personalizado que persegue interesses particulares. Por isso, segundo Zagrebelsky (2002), a lei não é mais garantia de estabilidade, ela mesma se converte em instrumento e causa de instabilidade, fato que determina a superação do Estado Legal de Direito.

Hespanha (2005) assinala que o vigor antilegalista das décadas que se seguiram à Segunda Guerra Mundial não é uma simples consequência dos movimentos de natureza filosófica no domínio do direito. O trágico contexto político dos totalitarismos contemporâneos teve enorme impacto sobre a consciência jurídica e obrigou a reavaliar a função do direito.

Uma coisa ficou clara. O formalismo da pandectística, com o relativismo axiológico que lhe andava ligado, não armava suficientemente os juristas para, enquanto juristas, se oporem a projetos políticos e jurídicos que negassem os valores fundamentais da cultura europeia. (HESPANHA, 2005, p. 49)

Até aquele momento histórico, anota Hespanha (2005), a legitimidade do direito fundava-se exclusivamente no fato de ser estabelecido de acordo com os procedimentos prescritos. Os seus valores de referência eram desprovidos de conteúdo e apontavam apenas para a necessidade de observar uma forma, e foi nessas circunstâncias que o nacional-socialismo subiu ao poder. No "[...] fim da guerra, gerou-se, portanto, um movimento espontâneo de refundamentação do direito em valores supra-positivos, indisponíveis para o legislador”. (HESPANHA, 2005, p. 470)

Segundo Prieto (1998), a crise provocou o deslocamento do Estado Legal para o Estado Constitucional, a afirmação do império da Constituição sobre a lei como forma de assegurar a máxima vinculação dos poderes do Estado. Este deslocamento, mais uma vez, proporciona alteração nos paradigmas da estrutura do direito, da ciência jurídica e da jurisdição. O resultado da crise é o reconhecimento da necessidade de que o ordenamento jurídico contenha uma lei com validade superior - a Constituição - e com força normativa (obrigatoriedade). Ao longo do século XX, na Europa, as normas constitucionais adquirem o status de normas jurídicas em sentido forte, superando-se o modelo no qual a Constituição era vista 
como um documento essencialmente político, cuja concretização ficava, invariavelmente, condicionada à liberdade de conformação do legislador ou à discricionariedade do administrador, sem espaço para o desempenho de qualquer papel relevante por parte dos órgãos do poder judicial.

De acordo com Barroso (2005), a reconstitucionalização da Europa, imediatamente após a Segunda Guerra Mundial e ao longo da segunda metade do século XX, redefiniu o lugar da Constituição e a influência do direito constitucional sobre as instituições contemporâneas, de modo que a aproximação das ideias de constitucionalismo e de democracia

[...] produziu uma nova forma de organização política, que atende por nomes diversos: Estado Democrático de Direito, Estado Constitucional de Direito, Estado Constitucional Democrático. (BARRO$\mathrm{SO}, 2005$, p. 23)

Assim, se a primeira mudança de paradigma do direito se deu com o nascimento do Estado Moderno e com a afirmação do princípio de legalidade como norma de reconhecimento do direito, uma segunda mudança, não menos radical, é a produzida na segunda metade do século XIX, com a subordinação das leis às Constituições rígidas, hierarquicamente superiores.

No Estado Constitucional, a validade das leis em geral não depende apenas da sua forma de produção, senão também da coerência de seus conteúdos com as normas constitucionais. A vigência das leis, que no paradigma positivista havia se dissociado da ideia de justiça, dissocia-se agora da ideia de validez formal, sendo possível que uma lei formalmente válida e, por conseguinte vigente, seja substancialmente inválida pelo contraste de seu significado com as normas constitucionais. Ocorre a superação do paradigma típico do Estado Legal de Direito, referente à estrutura do direito, porquanto agora só serão consideradas como leis válidas aquelas produzidas pela autoridade competente e de acordo com a forma previamente estabelecida, mas cujos conteúdos estejam em conformidade com as normas constitucionais.

Goyard-Fabre (2002, p. 112) assinala que a ideia-força do novo modelo é a de supremacia da lei constitucional, que é vista como o funda- 
mento de toda a ordem jurídica. Sob a Constituição, “[...] a catedral jurídica se organiza em sistema $[\ldots]$ ” e, neste, “[...] a ordem constitucional é portadora de normatividade, de modo que as regras de direito ganham figura, no âmbito estatal, de modelos de diretividade". Segundo Goyard-Fabre (2002, p. 117), para a "[...] teoria constitucionalista, o critério da legalidade não é outro senão a inscrição de uma regra ou a inserção de um comportamento no edifício jurídico que tem como pedra angular a Constituição". A Constituição é verdadeiramente a regra superior, "o estatuto matricial da institucionalização" (GOYARD-FABRE, 2002, p. 126), de modo que qualquer lei ou enunciado de direito só serão válidos se congruentes com a norma constitucional. A Constituição torna-se o critério de validade da ordem jurídica.

Zagrebelsky (2002, p. 34, tradução nossa), na mesma direção, observa que a principal novidade da fórmula é que a lei agora está subordinada a uma categoria mais alta do direito, a Constituição. "A lei, que antes fora medida exclusiva de todas as coisas no campo do direito, cede espaço para a Constituição e se converte, ela mesma, em objeto de medição"6. O legislador já não é mais soberano para editar leis com qualquer conteúdo, mas tem que ajustar sua política às exigências constitucionais.

O princípio da supremacia constitucional leva a uma primeira consequência de peso. O legislador ordinário, embora também se encontre limitado por regras de competência e procedimento (limites formais), está submetido agora às normas substantivas previstas na lei constitucional. Nesse caso, o limite que se lhe antepõe é material. Se, por exemplo, a lei constitucional, que vale mais, proíbe a pena de morte, o legislador ordinário já não pode instituí-la por meio da legislação penal.

O novo modelo incorpora ainda o predicado da rigidez constitucional, decorrente da atribuição às normas constitucionais de uma maior capacidade de resistência. A rigidez constitucional se subdivide em duas espécies de desigual intensidade. De um lado (rigidez relativa), ela implica que as normas constitucionais só podem ser modificadas por meio de um procedimento de revisão específico e agravado (emenda) na compa-

6 [...] la ley, un tiempo medida exclusiva de todas las cosas en el campo del derecho, cede así el paso a la Constitución y se convierte ella misma en objeto de medición. 
ração com as demais leis do ordenamento jurídico; de outro (rigidez absoluta), ela implica que determinadas cláusulas da lei constitucional não podem ser jamais abolidas, mesmo por meio de emendas constitucionais, porquanto são consideradas "referentes indisponíveis" em função da sua extraordinária importância. Enquanto o princípio da supremacia protege a Constituição contra o legislador ordinário, a rigidez normativa protege a Constituição contra a sua própria reforma, ora dificultando a alteração (no caso de normas com rigidez relativa), ora impedindo-a absolutamente (no caso de normas com rigidez absoluta). Assim, por exemplo, se a proibição da pena de morte consta da lei constitucional como uma norma relativamente rígida, sua adoção pela lei penal dependerá da aprovação prévia de uma emenda constitucional que a torne permissível, mas para tanto o legislador reformador terá que ultrapassar as barreiras de um procedimento rigoroso. Por outro lado, se a proibição da pena de morte consta da lei constitucional como um referente indisponível - ou seja, como "cláusula pétrea" -, a legislação penal jamais poderá adotá-la porque a Constituição não pode ser sequer modificada para autorizá-la.

Paralelamente, no Estado Constitucional, o papel do juiz se amplia consideravelmente. Ele não tem mais apenas a tarefa de decidir, nos casos litigiosos, se as condutas humanas estão ou não de acordo com a norma legal, ou seja, se existe ou não uma relação de adequação entre atos e leis. Em função da existência da Constituição e de sua supremacia, o juiz muitas vezes precisa antes examinar se a norma legal que é utilizada como medida da conduta humana está ou não contradição com alguma norma constitucional que esteja regulando a mesma matéria, ou seja, se existe ou não relação de adequação entre norma legal e norma constitucional. Em consequência, ele poderá, por exemplo, negar efeitos a um ato administrativo cujo fundamento é uma norma legal que, por estar em contradição com uma norma constitucional, deve ser descartada. Além disso, em função da rigidez absoluta, o juiz poderá ainda negar efeitos ao mesmo ato administrativo se o seu fundamento é uma norma constitucional que, resultante do processo de emenda constitucional, está em contradição a uma cláusula pétrea. Por isso, o Estado Constitucional se notabiliza por conter uma série de mecanismos processuais destinados a permitir e efetivar o controle de constitucionalidade. 
Contudo, a força normativa, a supremacia e a rigidez da Constituição, ao lado do controle de constitucionalidade, são apenas os meios de proteção. Embora engenhosos, eles são, em si mesmos, ideologicamente neutros, de modo que, em tese, são úteis para defender qualquer ordem jurídica fundamental, mesmo uma que porventura respalde a desigualdade entre os homens, a censura do pensamento ou o confisco de bens particulares. No Estado Constitucional, que reflete a experiência das modernas democracias ocidentais, estes meios são concebidos e agrupados em vista de um fim, que é a realização de uma peculiar concepção de justiça. Nesse sentido, o que joga um papel decisivo na configuração do novo modelo político-jurídico é "[...] a constitucionalização da carta de direitos - bill of rights -, ou seja, de um catálogo mais ou menos detalhado de direitos fundamentais"7 (POZZOLO, 2003, p. 188, tradução nossa). De fato, na linha da doutrina clássica dos direitos naturais (à vida, à liberdade, à propriedade, à igualdade) e do sistema de valores morais e de normas internacionais de direitos humanos, fundado sob o postulado do respeito incondicional à dignidade da pessoa humana, o direito constitucional contemporâneo reconhece aos indivíduos, como bem ressalta Zagrebelsky (2002), um "patrimônio de direitos" originário, considerado anterior à formação do próprio Estado, uma esfera jurídica que precede as estipulações do legislador.

O Estado Constitucional não se define, assim, tanto pelos meios de tutela que disponibiliza, mas pelos objetivos substantivos que são por esses meios tutelados, ou pelas normas atributivas de direitos considerados inalienáveis que demarcam o conteúdo ideológico da Constituição. É certo que o elenco de normas substantivas da Constituição não se esgota na declaração de direitos fundamentais. É próprio do Estado Constitucional, por exemplo, a consagração de princípios de organização política, como o da renovação dos mandatos por meio de eleições periódicas e da separação dos poderes estatais, enormemente importantes. Mas eles, mesmo que não sejam interpretados como atributivos de direitos em sentido estrito, ao fim e ao cabo, são institutos de reforço ou de projeção dos mesmos. Sem um judiciário independente, é improvável que os direitos resistam

[...] el argumento neoconstitucionalista parte del dato positivo de la constitucionalización del bill of rights, o sea, de un catálogo más o menos detallado de derechos fundamentales. 
aos atentados; sem alternância compulsória dos governantes por meio de eleições periódicas, é improvável que os direitos sejam adequadamente considerados e respeitados. Por isso, os direitos fundamentais são a essência do Estado Constitucional.

Nessa direção, segundo Peña (2003), a finalidade do Estado Constitucional é satisfazer os direitos. Tal objetivo se pretende alcançar fundamentalmente assegurando a primazia da Constituição e deixando os direitos atrincheirados mediante dois instrumentos ou garantias: a rigidez constitucional e o caráter normativo das Constituições. Miranda (1993), a propósito, registra que não se trata de proclamar solenemente direitos subjetivos do homem, mas de afirmá-los como princípios objetivos e institucionais do Estado, porquanto os direitos fundamentais são as bases do Estado, e a sociedade em que falte sua garantia não tem Constituição. Também Andrade (1998, p. 27-28) observa que a limitação efetiva do poder se alcança através da consagração constitucional dos direitos. Os direitos fundamentais tornam-se, assim, direitos constitucionais, reunindo "[...] as condições para que lhes seja reconhecida relevância jurídica positiva com um valor superior ao da própria lei”. Segundo o autor, “[...] o caráter constitucional dos direitos acabou sempre por gerar a garantia jurídica efectiva deles perante todos os poderes públicos, incluindo o poder legislativo". (ANDRADE, 1998, p. 27-28)

Naturalmente, a garantia dos direitos fundamentais, para ser efetiva e duradoura, depende da atribuição do predicado da rigidez absoluta às normas que os declaram. É que não basta que eles sejam imunes em face do legislador ordinário em razão da supremacia constitucional, nem que haja a previsão de um procedimento rigoroso que dificulte a alteração constitucional. É preciso que eles sejam considerados como pertencendo a uma esfera de indisponibilidade total, ou seja, não possam ser suprimidos ou reduzidos nem mesmo por meio de emenda e, como tal, sejam inacessíveis ao poder de reforma constitucional. Por isso, a associação entre direitos fundamentais e cláusulas pétreas é também uma das notas mais típicas do Estado Constitucional.

De fato, como argumenta Ferrajoli (1999, p. 51), a forma indisponível se revela como a técnica de tutela, por excelência, dos bens consi- 
derados fundamentais pelo pacto constitucional. Daí a sua conclusão de que os direitos fundamentais pertencem à "esfera do indecidível", bem como de que as normas que os consagram estão em princípio "dotadas de rigidez absoluta" ou são "supraordenadas a qualquer poder decisional". Cademartori (1999, p. 32) igualmente observa que o traço marcante do Estado Constitucional não está na subordinação do soberano a uma forma de agir, mas na proibição que lhe é oposta "de violar certos conteúdos, postos pela sociedade que o funda como intocáveis", precisamente os "denominados direitos fundamentais".

Para concluir, e por fidelidade à história, é agora necessário advertir que o Estado Constitucional é, para a Europa e para o Brasil, uma experiência tardia. O advento da Constituição dos Estados Unidos, que se segue à declaração de independência das colônias britânicas na América do Norte (1776) e às sucessivas declarações de direitos dos Estados federados, já assinalava uma expressiva ruptura com o formalismo jurídico, revelando a estruturação de um modelo político-jurídico que se antecipou em mais de um século à forma constitucional da generalidade das democracias ocidentais do mundo contemporâneo (Alemanha, Espanha, Portugal, Itália, Brasil, etc.).

$\mathrm{Na}$ América, a $1^{\mathrm{a}}$ Emenda, aprovada em 1789, dispôs que "[...] o Congresso não editará lei instituindo uma religião, ou proibindo o seu exercício; nem restringirá a liberdade de palavra ou de imprensa; ou o direito de o povo reunir-se pacificamente, ou o de petição ao governo para a correção de injustiças". Posteriormente, a 14 a Emenda (1868) declarou que "[...] nenhum Estado fará ou executará nenhuma lei, com efeito de reduzir as prerrogativas ou imunidades dos cidadãos dos Estados Unidos; nem tampouco Estado algum privará uma pessoa de sua vida, liberdade ou bens, sem o devido processo legal; nem denegará a alguma pessoa, dentro de sua jurisdição, a igual proteção das leis". Em ambos os casos, estamos diante de normas constitucionais que expressamente pretendem estabelecer limites de conteúdo ao direito ordinário, com a diferença de que, no primeiro, a restrição se dirige ao legislativo federal e, no segundo, ao legislativo estadual. O dado notável é que, poucos anos mais tarde, a Constituição dos Estados Unidos passou a contar com um reforço de grande originalidade na história das instituições, o surgimento da consciência 
da supremacia das leis constitucionais e da possibilidade do controle judicial de constitucionalidade (judicial review). No julgamento do célebre caso Marbury ver Madison, em 1803, a Suprema Corte positivou ambas as garantias ao qualificar a Constituição como "superior paramount law, unchangeable by ordinary means" e ao afirmar que "a legislative act contrary to the constitution is not law". Além disso, nos Estados Unidos, as cláusulas pétreas do constitucionalismo europeu e brasileiro - que indicam as normas constitucionais dotadas de rigidez absoluta - encontram equivalente parcial na doutrina das entrenchment clauses, bem como na ideia de inalienabilidade dos direitos e no propósito de "[...] assegurar as bênçãos da liberdade [...] para a nossa posteridade [...]”, conforme declara o preâmbulo da Constituição. Por conseguinte, Comparato (1999, p. 95) parece estar coberto de razão quando afirma que o constitucionalismo, em sua acepção moderna, é "uma criação norte-americana".

\section{Os Direitos Fundamentais}

As normas de direitos fundamentais integram a parte substantiva da lei constitucional. Elas não dispõem sobre competências e procedimentos a observar no processo legislativo. Antes, elas conferem às pessoas a aptidão de exigir da autoridade pública (governos, legisladores, etc.), bem como de seus semelhantes, o respeito a certas faculdades de ação, esferas de incolumidade pessoal e patrimonial ou a satisfação de determinadas pretensões que são reputadas como dignas de proteção jurídica especial e absoluta. Nesse sentido, os direitos fundamentais são normas de conteúdo, e não de forma. Na Constituição, eles são normalmente declarados através de fórmulas abreviadas e grandiloquentes, do tipo "todos são iguais perante a lei", "é livre a manifestação do pensamento", "é assegurada a liberdade de crença e de consciência", "é garantido o direito de propriedade", "é inviolável a intimidade das pessoas" ou, ainda, "ninguém será submetido à tortura nem a tratamento desumano ou degradante".

Os direitos fundamentais declarados na Constituição das modernas democracias estão em estreita correlação com uma figura próxima, a dos direitos humanos, cuja afirmação em nível global é o resultado de um 
longo processo histórico. Em um texto primoroso, Comparato (1999) descreveu em pormenor os antecedentes e as proclamações mais representativas deste percurso. Parte delas, como as inglesas, as norte-americanas e as francesas, espelham experiências locais, mas que foram indutoras, ao lado de outros fatores, da assertividade universal dos direitos humanos através de tratados e convenções internacionais. Em conjunto, elas constituem referências imprescindíveis à compreensão do conteúdo das normas constitucionais de direitos fundamentais, ou do tipo de interesses, expectativas ou aspirações humanas que as mesmas visam a resguardar.

A história começa na Inglaterra ainda medieval. A Magna Carta, assinada em 1215 pelo monarca João da Inglaterra - também conhecido como João Sem-Terra - perante o alto clero e os barões do reino, assinala a primeira restrição institucional dos poderes do rei em face dos dois estamentos privilegiados, a nobreza e o clero. Ela limita o poder real de taxação, lança as bases do tribunal do júri, admite a autonomia da jurisdição e garante a propriedade privada contra confiscos e requisições do soberano. Quatro séculos à frente, a Lei de Habeas Corpus (1679) estabelece a obrigação de que os súditos acusados de práticas criminosas e mantidos na prisão sejam, em prazo exíguo, ou incontinenti, apresentados perante a autoridade judiciária. Em seguida, a declaração de direitos conhecida como Bill of Rigths (1689), imposta pelo parlamento ao príncipe Guilherme de Orange como condição negociada de sua ascensão ao trono inglês, institucionaliza a separação dos poderes como mecanismo de garantia de direitos. Competências próprias são reconhecidas ao parlamento, que passa a ser entendido como órgão de defesa do súdito perante o rei. $\mathrm{O}$ direito de petição ao poder real resta assegurado. As penas cruéis e inusitadas são proibidas, a instituição do júri é fortalecida.

A declaração de independência dos Estados Unidos (1776) merece destaque como o primeiro documento a reconhecer, além do princípio da soberania popular como fonte de legitimação do poder, a existência de direitos inerentes a todo ser humano (tais como, à liberdade, à vida e à busca da felicidade), independente das diferenças de sexo, raça, religião, cultura ou posição social. As declarações de direitos norte-americanas que se seguem à declaração de independência, com ênfase para a da Virgínia (1776), e as dez primeiras emendas à Constituição norte-americana 
(entre 1789 e 1791), consagram a ideia de direitos inatos (de caráter individualista), a partir de então elevados à categoria de direitos positivos, sancionados pelo poder estatal. Com a mesma sintaxe, a Declaração dos Direitos do Homem e do Cidadão de 1789 (França), contemporânea da Revolução Francesa, reconhece a igualdade, a liberdade, a propriedade, a segurança e a resistência à opressão como direitos naturais e imprescritíveis, ressaltando que sua conservação é o fundamento do Estado. A Constituição Francesa de 1848 avança estipulando deveres sociais para o poder público e abolindo a pena de morte em matéria política.

No século seguinte, a Convenção de Genebra (1864), assinada unicamente por potências europeias, inaugura o que se convencionou chamar de direito humanitário, isto é, o conjunto de leis e costumes de guerra destinados a minorar o sofrimento de soldados feridos e doentes, bem como de populações civis atingidas por um conflito bélico. O Ato Geral da Conferência de Bruxelas (1890), subscrito por 17 Estados, regulamenta medidas de repressão ao tráfico de escravos africanos.

No século XX, a Constituição Mexicana de 1917 surge como a primeira a reconhecer a dimensão social dos direitos humanos ao atribuir aos direitos trabalhistas a qualidade de fundamentais e ao afirmar o caráter relativo do direito de propriedade, lançando as bases do Estado Social de Direito. A Constituição Alemã de 1919, dita de Weimar, cidade onde foi elaborada e votada, seguindo-se à Constituição Mexicana, inclui vários direitos de natureza social no catálogo dos direitos fundamentais (educação, trabalho, previdência, função social da propriedade, etc.), desenhando uma estrutura já mais bem elaborada de Estado, que combina os direitos civis e políticos negados pelo comunismo com os direitos econômicos e sociais ignorados pelo capitalismo. A doutrina social da igreja romana teve aqui influência considerável. Em 1891, enfrentando o tema da condição dos operários na carta encíclica Rerum Novarum, o Papa Leão XIII (1991) já defendia que os governos devem atenção a todas as classes, mas competindo-lhes cuidar de maneira especial dos fracos, e preconizava, em proveito da multidão proletária, a mobilização da providência estatal, a liberdade de associação, a limitação da jornada de trabalho, um tratamento diferenciado às mulheres, crianças e aos encarregados de serviços pesados, a garantia do repouso semanal e de um salário justo, bem 
como sustentava, numa posição avançada no tempo, a nulidade dos contratos de trabalho iníquos.

No plano internacional, a Convenção de Genebra (1926) sobre a escravatura se propõe a revisar e atualizar o Ato Geral da Conferência de Bruxelas de 1890. A convenção relativa ao tratamento de prisioneiros de guerra, assinada em Genebra em 1929, em documento extenso e minucioso, regula a captura, o cativeiro, a organização dos campos de prisioneiros, as relações destes com o mundo exterior, os escritórios de ajuda e informação, entre outros. A Carta das Nações Unidas, subscrita após a Segunda Guerra Mundial por 51 países, constituiu o ato de fundação da Organização das Nações Unidas (ONU) em 1945. Nela, os signatários se comprometem a favorecer o respeito universal aos direitos humanos e às liberdades fundamentais para todos, sem discriminações de qualquer natureza. Ato contínuo, adota-se a Declaração Universal dos Direitos do Homem (1948), que se abre com a proclamação dos três princípios axiológicos fundamentais em matéria de direitos humanos (a liberdade, a igualdade e a fraternidade) e adiante afirma, entre outros, o direito de todos os homens à vida, à liberdade, à segurança pessoal, de asilo e à nacionalidade, a proibição da escravidão e, ainda, a democracia como única forma de governo compatível com o respeito aos direitos humanos. Seguem-se a ela a Convenção para a Prevenção e a Repressão do Crime de Genocídio (1948) e, ainda, as convenções de Genebra (1949) sobre a Proteção das Vítimas de Conflitos Bélicos.

A Convenção Europeia dos Direitos Humanos (1950) reconhece o indivíduo como sujeito de direito internacional e institui órgãos incumbidos de fiscalizar o respeito aos direitos nela declarados e a julgar as suas eventuais violações pelos Estados signatários. Em 1966, é adotada a Convenção Internacional Sobre a Eliminação de Todas as Formas de Discriminação Racial. Os Pactos Internacionais de Direitos Humanos (1966), divididos no Pacto Internacional sobre Direitos Civis e Políticos e no Pacto Internacional sobre Direitos Econômicos, Sociais e Culturais, desenvolvem pormenorizadamente o conteúdo da Declaração Universal de 1948. A Convenção Americana de Direitos Humanos (1969), que reproduz o conteúdo dos Pactos de 1966, traz inovações expressivas, tais como, o princípio da prevalência do sistema normativo mais vantajoso 
para a pessoa e no tocante à punição da usura e da exploração do homem pelo homem.

Já próximo dos nossos dias, a Convenção relativa à Proteção do Patrimônio Mundial, Cultural e Natural (1972) proclama, pela primeira vez, a existência de um "direito da humanidade", tendo por objeto bens que pertencem a todo gênero humano. A Carta Africana dos Direitos Humanos e dos Direitos dos Povos (1981) inova com a afirmação de que os povos também são titulares de direitos humanos (à existência, ao meio ambiente sadio, à paz, à livre disposição de sua riqueza, ao desenvolvimento, etc.), tanto no plano interno como externo. A Convenção sobre o Direito do Mar (1982) afirma os direitos da humanidade inteira sobre mares e oceanos, subtraindo, por exemplo, os recursos minerais, sólidos ou gasosos, localizados fora das áreas de jurisdição de cada Estado, à exploração capitalista e à apropriação por um Estado particular. Finalmente, a Convenção sobre a Diversidade Biológica (Rio de Janeiro, 1992), incorporando o princípio da solidariedade entre as gerações atuais, bem como entre estas e as futuras gerações, regula o direito da humanidade à preservação do equilíbrio ecológico do planeta.

Segundo Comparato (1999, p. 1), o que se contém na narrativa das circunstâncias e das proclamações que induziram e consolidaram a afirmação dos direitos humanos em escala mundial "[...] é a parte mais bela e importante de toda a história [...]", a revelação do reconhecimento de que “[...] todos os seres humanos, apesar das inúmeras diferenças biológicas e culturais que os distinguem entre si, merecem igual respeito, como únicos entes do mundo capazes de amar, descobrir a verdade e criar a beleza". Trata-se, de fato, da evidência empírica de que, apesar da compreensível relatividade dos sistemas morais, existe uma ordem mínima de valores compartilhados, que se orienta a partir da identificação do conceito de justiça com o respeito à dignidade do homem. E, realmente, como já o disse Bobbio (1992, p. 27) em passagem célebre, “[...] a Declaração Universal dos Direitos do Homem pode ser acolhida como a maior prova histórica até hoje dada do consensus omnium gentium sobre um determinado sistema de valores". 
A história é bela, obviamente, apenas em termos. O sistema de valores morais e de normas internacionais de direitos humanos é reativo e defensivo. A fonte do consenso em torno da ideia dos direitos do homem não é nem a benevolência nem a sabedoria espontâneas de um mundo sem problemas. Antes, o que realmente leva à sua aceitação generalizada é - roubando de Dershowitz (2004) o argumento -, a experiência humana com a injustiça, com os terríveis horrores das cruzadas, da inquisição, da escravidão, da colonização, do holocausto, das deportações, dos genocídios, do terrorismo, do apartheid, das guerras, da fome. É isso que se deve entender quando, nos considerandos de seu preâmbulo, a Declaração Universal dos Direitos do Homem, justificando-se a si própria, faz remissão aos "atos bárbaros que ultrajaram a consciência da humanidade". Os direitos do homem são luzes, sim, mas são luzes sobre trevas. Sua proclamação formal tem o propósito prioritário de, compromissando os governos e as nações locais, tentar evitar a repetição ou a recorrência de contextos políticos e práticas abomináveis.

No sistema de direitos humanos, a ideia transcendente é, enfim, a de que o respeito à dignidade humana é o valor supremo da vida em comunidade. O homem, qualquer homem, não é nem coisa nem bicho. É pessoa, ser dotado de razão, capacidade de autodeterminação e aspirações de felicidade. Para realizar seu destino singular no mundo, o homem precisa estar protegido, por meio da atribuição de direitos, contra quaisquer atos cujo efeito seja a negação de sua condição. Ele não pode ser considerado um ser inferior em relação aos demais; não pode ser escravizado; a força de seu trabalho não pode ser explorada sem compensação econômica adequada, a um preço vil; sua vida não pode ser arbitrariamente retirada; suas crenças, suas convicções e suas ideias não podem ser silenciadas; ele não pode ser por elas punido, menos ainda supliciado; ele não pode ser impedido de reunir-se com outros, de tomar parte no governo de seu país e de interferir na política; não pode ser encarcerado sem que tenha sido possível defender-se perante um juiz independente e imparcial, no curso de um processo justo; não pode ser classificado como culpado de crimes e ilícitos antes do julgamento definitivo; suas posses não podem ser sumariamente confiscadas; sua intimidade não pode ser devassada, e sua honra e reputação, difamadas; ele não pode ser abandonado na doen- 
ça, na invalidez, na velhice; não pode deixar de ter acesso à escola e aos serviços sociais.

No Estado Constitucional, as normas de direitos fundamentais representam a assimilação, por assim dizer, desses preceitos de justiça que, no marco da sociedade ocidental, sob o peso de séculos e séculos de injustiças e sob a influência do jusnaturalismo filosófico, da doutrina cristã e do liberalismo político, acabaram finalmente por reunir as consciências em torno de um projeto elementar de mundo. Embora apresentem divergências de ênfase e extensão conforme a Constituição particular de cada país, as normas de direitos fundamentais, de um modo geral, reproduzem os aspectos centrais do sistema de valores morais e normas internacionais que atualmente se encontra justamente sintetizado e materializado na Declaração Universal dos Direitos do Homem. Desse modo, tais normas refletem na ordem constitucional das comunidades nacionais o sentido essencial do postulado da dignidade da pessoa humana, contemplando habitualmente o seu núcleo axiológico básico, vale dizer, a defesa da vida, da igualdade, da liberdade, da propriedade, do trabalho, da democracia e da solidariedade.

\section{Conclusão}

O Estado Constitucional de Direito é um sistema de garantias. A força normativa, a supremacia e a rigidez da lei constitucional, ao lado dos mecanismos de controle de constitucionalidade, são os meios de garantia. $\mathrm{O}$ respeito à dignidade do homem, como condição de justiça, é o objetivo primordial da garantia. A unidade do sistema - de seus meios e de seus fins - se realiza através da positivação (ou "legalização") dos assim chamados direitos fundamentais, que constituem, por isso, a categoria central do constitucionalismo contemporâneo, a nova fronteira da experiência jurídica. Com efeito, na medida de sua aceitação e recriação na Constituição de cada nação sob a forma de direitos fundamentais, os direitos do homem, ditos naturais e inalienáveis, passam a desfrutar do mais contundente grau de proteção jurídica, tornando-se beneficiários das técnicas de tutela próprias do Estado Constitucional. A de maior relevo é, 
sem dúvida, a da rigidez normativa absoluta, que os põe a salvo inclusive do poder de reforma constitucional. Essa é uma consequência facilmente compreensível porque, uma vez estando preordenados à realização concreta do princípio da dignidade da pessoa humana, os direitos humanos equivalem a bens jurídicos sem cuja proteção efetiva se entende que não é possível uma existência enobrecedora para o homem e, por isso, têm de ser catalogados como irrevogáveis. Em segundo lugar, em função da supremacia da Constituição, os direitos fundamentais caracterizam-se como imunes em face do legislador ordinário, que está proibido de fazer ou manter leis que impliquem a sua denegação. Além disso, os direitos fundamentais são defensáveis por mecanismos processuais de arguição de inconstitucionalidade, quer sob o método de controle abstrato, quer sob o método de controle concreto. Alguns direitos fundamentais gozam ainda, para sua proteção, de ações ou remédios constitucionais específicos, como por exemplo, no caso brasileiro, o habeas corpus, a ação popular, o mandado de injunção, o habeas data ou, ainda, o mandado de segurança. Por fim, embora o desígnio predominante dos direitos fundamentais seja conter a tendência e o risco de opressão por parte dos governos, eles são também coativamente exigíveis no plano das relações interpessoais, ou dos indivíduos entre si. Todo esse arsenal de meios de proteção está articulado em vista de um fim peculiar, a efetivação da ideia de justiça que encontra sua identidade na doutrina clássica dos direitos naturais e, sobretudo, no sistema de valores morais e de normas internacionais de direitos humanos, em favor dos quais a maior parte da humanidade presta hoje o seu consentimento. Por isso, mais do que um Estado de Direito, o Estado Constitucional é, em verdade, um Estado de Justiça.

\section{Referências}

ANDRADE, José Carlos Vieira de. Os direitos fundamentais na

Constituição Portuguesa de 1976. Coimbra: Almedina, 1998. 350 p.

BARROSO, Luís Roberto. Fundamentos teóricos e filosóficos do novo direito constitucional brasileiro (pós-modernidade, teoria crítica e pós-positivismo). In: BARROSO, Luís Roberto. (Org.). A nova 
interpretação constitucional: ponderação, direitos fundamentais e relações privadas. Rio de Janeiro: Renovar, 2003, p. 1-48.

. Neoconstitucionalismo e Constitucionalização do Direito (O Triunfo Tardio do Direito Constitucional no Brasil). Revista Brasileira de Direito Público, Belo Horizonte, v. 11, p. 21-65 out.-dez. 2005,. BOBBIO, Norberto. A era dos direitos. 8. ed. Tradução de Carlos Nelson Coutinho. Rio de Janeiro: Campus, 1992. 217 p.

CADEMARTORI, Sergio. Estado de direito e legitimidade: uma abordagem garantista. Porto Alegre: Livraria do Advogado, 1999. 188 p. CANOTILHO, J. J. Gomes. Direito constitucional e teoria da constituição. 3. ed. Coimbra: Almedida, 1999. 1.414 p.

COMPARATO, Fábio Konder. A Afirmação histórica dos direitos humanos. São Paulo: Saraiva, 1999. 421 p.

DERSHOWITZ, Alan. Rights and wrongs: a secular theory of the origins of rights. New York: Basic Books, 2004. 261 p.

FERRAJOLI, Luigi. Derechos y garantías: la ley del más débil. Tradução de Perfecto Andrés Ilbañez e Andrea Greppi. Madrid: Trotta, 1999. $180 \mathrm{p}$.

. Pasado y futuro del Estado de Derecho. Tradução de Pilar Allegue. In: CARBONELL, Miguel (Org.). Neoconstitucionalismo (s), Madrid: Trotta, 2003, p. 13-29.

GOYARD-FABRE, Simone. Os fundamentos da ordem jurídica. Tradução de Claudia Berliner. São Paulo: Martins Fontes, 2002. 376 p. HESPANHA, Antonio Manuel. Cultura Jurídica Européia: síntese de um novo milênio. Florianópolis: Fundação Boiteux, 2005. 551 p.

HOBBES, Thomas. Leviatã ou matéria, forma e poder de um estado eclesiástico e civil (os pensadores). 3. ed. Tradução de João Paulo Monteiro e Maria Beatriz Nizza da Silva. São Paulo: Abril Cultural, 1983. 419 p.

HOBBES, Thomas. Do cidadão. Tradução Renato Janine Ribeiro. São Paulo: Martins Fontes, 1998. 400 p. 
LEÃO XIII. Rerum novarum. In: Encíclicas e documentos sociais. Tradução Antonio De Sanctis. São Paulo: LTr, 1991. p. 13-47. v. 1.

LOCKE, John. Segundo tratado sobre o governo. Tradução de E. Jacy Monteiro. In: Os pensadores. São Paulo: Abril Cultural, 1973, p. 213-313. MIRANDA, Jorge. Manual de direito constitucional. Tomo IV. Direitos Fundamentais. 2. ed. Coimbra: Coimbra, 1993. 485 p.

PEÑA, Antonio Manuel. Constitucionalismo Garantista y Democracia. Revista Crítica Jurídica, Curitiba, n. 22, p. 33-51, 2003.

POZZOLO, Suzana. Un constitucionalismo ambiguo. (Org.). Tradução Miguel Carbonell. In: CARBONELL, Miguel. Neoconstitucionalismo (s). Madrid: Trotta, 2003, p. 187-210.

PRIETO SANCHÍS, Luis. Ley, principios, derechos. Madrid: Dykinson,1998. $127 \mathrm{p}$.

ZAGREBELSKY, Gustavo. EI derecho dúctil. Tradução de Marina Gascón. 4. ed. Madrid: Trotta, 2002. 156 p.

João dos Passos Martins Neto é professor dos Cursos de Graduação e PósGraduação em Direito da Universidade Federal de Santa Catarina. Doutor em Direito pela Universidade Federal de Santa Catarina. Visiting Scholar na Columbia University School of Law (2007-2008). Procurador do Estado de Santa Catarina.E-mail: passos@pge.sc.gov.br.

Endereço profissional: Universidade Federal de Santa Catarina

Campus Universitário, s/n, Trindade, Florianópolis, SC.

Caixa Postal 476. CEP: 88040-900.

Bárbara Lebarbenchon Moura Thomaselli é procuradora do Estado de Santa Catarina. Juíza Substituta do Tribunal Regional Eleitoral de Santa Catarina. Mestre em Direito pela Universidade Federal de Santa Catarina. E-mail: barbara@pge. sc.gov.br.

Endereço profissional: Avenida Prefeito Osmar Cunha, 220, Centro, Florianópolis, Santa Catarina. CEP: 88015-100. 